\section{Estimate of genetic parameters in Brachiaria decumbens hybrids}

\author{
Filipe Inácio Matias ${ }^{1}$, Sanzio Carvalho Lima Barrios ${ }^{2 *}$, Cacilda \\ Borges do Valle ${ }^{2}$, Rogério Gonçalves Mateus ${ }^{3}$, Lucas Bearari \\ Martins $^{4}$ and Gustavo Vitti Moro ${ }^{1}$
}

\begin{abstract}
The objective of this study was to estimate genetic parameters for agronomic traits and nutritional value in intraspecific hybrids of $B$. decumbens. For this, a population of 1,415 hybrids was evaluated in field plots at Embrapa Beef Cattle in Campo Grande/MS/Brazil, with seven clippings in order to estimate field green weight (FGW); total dry matter (TDM); speed of regrowth $(S R)$; tiller regrowth density (TRD); regrowth ability (REG); crude protein $(C P)$; in vitro organic matter digestibility (IVD); neutral detergent fiber (NDF) and lignin (LIG). The statistical analyses were carried out using the mixed models methods. Genetic variability for all traits assessed was detected, and estimates of individual heritability were of medium to high magnitude, indicating the possibility of gains with selection. Significant genetic correlations were observed between FGW and TDM (0.99), TDM and SR (0.81), TDM and IVD (-0.71), TDM and LIG (0.71), and CP and IVD (0.70).
\end{abstract}

Key words: Urochloa decumbens, signalgrass, recurrent selection, heritability.

\section{INTRODUCTION}

The need for new cultivars of tropical forages to better comply with the demands of the livestock sector has influenced and stimulated the development of breeding programs for the most important commercial species (Valle et al. 2009, Alves et al. 2013). These programs constantly search for new genotypes that simultaneously combine agronomic performance, nutritional value and resistance to pest and diseases that surpass the standards of the existing cultivars in the market (Jank et al. 2014).

The genetic improvement of Brachiaria decumbens (synonym Urochloa decumbens) could not be done in a recent past due to the absence in the available germplasm of sexual genotypes compatible with the tetraploid and apomictic cv. Basilisk, the only cultivar of $B$. decumbens available commercially. A diploid accession of this species was duplicated using colchicine, resulting in three sexual and tetraploid plants (Simioni and Valle 2009), which allowed for intraspecific crosses and for the attainment of a base population of 457 hybrid progenies (Jank et al. 2011). These progenies, unprecedented in the world, granted the opportunity to finally exploit the genetic variability in $B$. decumbens by means of recombination and selection, in order to increase the frequency of favorable alleles for the main traits.

This paper reports the beginning of a recurrent selection (RS) program based
Crop Breeding and Applied Biotechnology 16: 115-122, 2016 Brazilian Society of Plant Breeding. Printed in Brazil http://dx.doi.org/10.1590/1984$70332016 v 16 n 2 a 18$

\footnotetext{
*Corresponding author: E-mail: sanzio.barrios@embrapa.br
}

Received: 12 December 2014 Accepted: 22 June 2015

${ }^{1}$ Universidade Estadual Paulista "Júlio de Mesquita Filho" (UNESP), Faculdade de Ciências Agrárias e Veterinárias, Campus de Jaboticabal, via de acesso Prof. Paulo Donato Castellane, s/n, 14.884-900, Jaboticabal, SP, Brazil

2 Embrapa Gado de Corte, Av. Rádio Maia, 830, Zona Rural, 79.106-550, Campo Grande, MS, Brazil

${ }^{3}$ Universidade Federal de Mato Grosso do Sul, Cidade Universitária, C. P. 549, 79.070900, Campo Grande, MS, Brazil

${ }^{4}$ Universidade Estadual de Mato Grosso do Sul (UEMS), Unidade de Aquidauana, Rod. Aquidauana, km 12, C. P. $25,79.200-000$, Aquidauana, MS, Brazil 


\section{FI Matias et al.}

on the specific combining ability in $B$. decumbens, a cyclical breeding strategy that aims at attaining superior apomictic hybrids in this species. In RS, a sexually reproducing breeding population can be selected based on the performance of the hybrid progenies formed by crosses of each of a series of sexual clones with a single apomictic tester genotype (Miles 2007). A population of 1,415 intraspecific hybrids of $B$. decumbens was obtained at Embrapa Beef Cattle Center by crossing 75 sexual hybrids from the base population of $B$. decumbens with cv. Basilisk (Barrios et al. 2013). The objective of this work was to estimate the genetic parameters for the main agronomic and nutritive value traits in this recurrent selection population of $B$. decumbens, based on the specific combining ability.

\section{MATERIAL AND METHODS}

Three artificially tetraploidized sexual plants (Simioni and Valle 2009) were initially crossed to the apomictic cv. Basilisk. From these crosses, 457 intraspecific hybrids were obtained, which constituted the base population (cycle zero) of the $B$. decumbens breeding program. Seventy-five hybrids were then selected from this population and used as female plants in new crosses with cv. Basilisk, which was used as pollen donor in a recurrent selection scheme based on specific combining ability. One thousand, four hundred and fifteen hybrids were obtained from the 75 full-sib progenies, which were individually evaluated in experimental plots. Seeds were germinated in tubes, and then transplanted to the field at Embrapa Beef Cattle Center in Campo Grande/MS, in December 2012, in a Distroferric Latossol, and clipped seven times (five times in the rainy season and twice in the dry season). The experimental design was a randomized block (DBC) with four blocks and five plants per plot, evaluated individually, spaced $1.5 \mathrm{~m}$ between plants, and $1.5 \mathrm{~m}$ between lines, with an experimental area of $11.25 \mathrm{~m}^{2}$ in the plot. An external border was planted with Panicum maximum cv. Massai around the whole experiment.

The agronomic traits evaluated in each individual plant of the plot were: field green weight (FGW) in g plant ${ }^{-1}$; total dry matter (TDM), in kg ha-1; visual scores for speed of regrowth (SR) and for tiller regrowth density (TRD); and SR and TRD, which were evaluated seven days after each clipping. The final regrowth score (REG) was given combining both tiller density regrowth score and speed of regrowth score ( $1=$ less than $20 \%$ of tillers regrown; $2=20$ to $40 \% ; 3=40$ to $60 \% ; 4=60$ to $80 \%$; and $5=$ more than $80 \%$ ) and speed of regrowth ( $1=$ low; $2=$ medium and $3=$ high $)$, as described by Figueiredo et al. (2012).

The weight of the each clipped plant (FGW) was recorded in the field using a scale, and a sample of about $150 \mathrm{~g}$ was then collected to determine the dry matter percentage, in order to calculate TDM. The agronomic traits were evaluated for each plant in the plot, in each of the seven clippings, of which five were during the rainy season (March 26 $6^{\text {th }}, 2013$; May 15 $5^{\text {th }}, 2013$; December $12^{\text {th }} 2013$; June $6^{\text {th }}, 2014$; and April $2^{\text {th }}, 2014$ ), and two in the dry season (June $18^{\text {th }}, 2013$; and October $\left.16^{\text {th }}, 2013\right)$.

The traits related to nutritive value were evaluated in three different clippings (two in the rainy and one in the dry season). For that, a green forage sample of about $80 \mathrm{~g}$ was taken simulating grazing in each plant. Those samples were dried and ground to be analyzed using a near infrared analyzer (NIRS), as indicated by Marten et al. (1985). The traits were: crude protein (CP), in vitro dry matter digestibility (IVD), neutral detergent fiber (NDF) and lignin (LIG). The simulated grazing samples were taken the day before the clippings: on May 15 ${ }^{\text {th }}, 2013$ and December $11^{\text {th }}$ 2013, in the rainy season, and on October $15^{\text {th }} 2013$, in the dry season.

A mixed models approach (REML/BLUP), using the SELEGEN REML/BLUP (Resende 2007) software was used for statistical analysis. Since the agronomic and nutritive value traits were evaluated by several clippings in the same experimental unit (repeated measures in time), an individual analysis was first carried out for each clipping, and afterwards a group analysis was carried out for the two seasons, and finally for all clippings grouped. The linear mixed model used was:

$$
y=X r+W g+T i+Z b+Q s+S p+e, \text { where: }
$$

$y$ is the data vector; $r$ is the vector for the effect of the replication-evaluation combination (fixed) added to the general mean; $g$ is the vector for the effect of the population genotypes (random); $i$ is the vector for the effects of the genotype $x$ clipping interaction (random); $b$ is the vector for the block effect (random); $s$ is the vector of the permanent effect of the individual (random); $p$ is the vector for the plot effect (random); and $e$ is the vector for the error or residue (random). The capital letters represent the incidence matrices for the respective effects. 
For the nutritive value traits in the dry season, since only one clipping was used, the following linear mixed model was used (full-sib evaluation in one place, and several observations per plot):

$$
y=X r+Z g+W p+e, \text { where: }
$$

$y$ is the data vector; $r$ is the vector for the replication effect (fixed) added to the general mean; $g$ is the vector for the effect of the individual genotypes (random); $p$ is the vector for the plot effect (random); and $e$ is the vector for the error or residue (random). The capital letters represent the incidence matrices for the respective effects.

The following components of variance and genetic parameters were estimated, using the joint analyses as reference: genotypic variance $\left(\sigma_{g}^{2}\right)$; variance of the genotype $x$ clipping interaction $\left(\sigma_{g c}^{2}\right)$; individual narrow sense total heritability, adjusted for the effects of the model $\left(h_{a t c}^{2}\right)$; heritability among progeny means $\left(h_{m}^{2}\right)$; accuracy (Acgen); repeatability on clipping means $\left(r_{m}\right)$; genotypic correlation among clippings (rgmed); overall mean $(\bar{X})$; and ratio of the difference between maximum and minimum predicted genotypic value and the overall mean (Range). The genotypic values for the progenies were predicted for each trait, and the variance components were estimated using residual maximum likelihood. The components of variance were tested using the likelihood ratio test (LRT) and the significance verified by the Chi-square test with 1 degree of freedom.

In order to verify the genetic correlations $\left(r_{G_{(x, y)}}\right)$ amongst the agronomic and nutritive values traits, after the joint analysis of all clippings, data were analyzed using the 102 model of Selegen Reml/Blup software to obtain the correlation estimates. The significance of the genetic correlation was verified using an approximate Student's $t$ test (Steel et al. 1997), considering $n-2$ degrees of freedom, where $n$ is the number of genotypes.

\section{RESULTS AND DISCUSSION}

For most of the traits analyzed, the presence of genetic variability among hybrids was detected regardless of the season of the year, with the exception of IVD in the rainy season and REG in the dry season. However, considering the joint analysis, there was genetic variability $(p<0.01)$ for all traits (Table 1$)$. The presence of genetic variability is essential to obtain selection gains in a breeding program (Ramalho 2005, Valle et al. 2009, Cruz et al. 2012). Thus, there is a clear perspective of gains with selection for both agronomic and nutritive value traits with results obtained for the intraspecific B. decumbens hybrids considered here.

The interaction genotype $x$ clippings $\left(\sigma_{g c}^{2}\right)$ was significant for all traits, both in the joint analysis for all clippings, as well as for season of the year. For the nutritive value traits it was not possible to estimate $\sigma_{g c}^{2}$ in the dry season since they were evaluated for a single clipping. Results indicate that the performance of the hybrids was not uniform for the different seasons (rainy and dry), as well as among clippings within the same season (Table 1). Significant estimates of $\sigma_{g c}^{2}(p<0.01)$ were also reported by Mendonça et al. (2013) on the evaluation of $50 B$. decumbens hybrids using six clippings (four in the rainy and two in the dry season) also for agronomic and nutritive value traits, except for NDF and LIG. Mateus et al. (2013) also found genotype x clippings interaction $(p<0.01)$ when evaluating $324 B$. decumbens hybrids for agronomic performance using two dry season clippings, with exception of REG and leaf/stem ratio.

Narrow sense individual heritability estimates $\left(h_{a t c}^{2}\right)$ varied from 0.13 for IVD to 0.61 for FGW in the joint analysis considering all clippings. The agronomic traits FGW and TDM had higher individual heritability estimates amongst all traits evaluated considering either the joint analysis or the seasons separately, with special performance in the dry season when both traits had $h_{a t c}^{2}$ estimates above 0.60. For the other traits, the $h_{a t c}^{2}$ estimates were of lower magnitude (Table 1), suggesting that the gains through selection for FGW and TDM will probably be more substantial than for the other traits.

When considering the estimates of heritability among progeny means $\left(h_{m}^{2}\right)$ for all the traits in the joint analysis, it was observed that they were of medium to high magnitude, ranging from 0.51 to IVD to 0.79 for FGW, indicating the possibility of high genetic gains with the selection of superior progenies for the next cycle of crosses. In the rainy season, estimates of $h_{m}^{2}$ for the agronomic variables, NDF and LIG stood out in relation to those of CP and IVD, which were of lower magnitude (Table 1). However, when checking the analyses of individual clippings, both for the rainy and the dry season, this association was not observed, and the estimates of $h_{m}^{2}$ were similar between agronomic and nutritional value traits (results not presented). 


\section{FI Matias et al.}

In general, tropical forages tend to decrease growth during the dry season, as observed in B. ruziziensis (Souza Sobrinho et al. 2011) and B. decumbens (Mendonça et al. 2013). This occurs due to various abiotic factors in the environment that directly affect the metabolism of plants, such as the reduction of daylight, temperature and rainfall, which is common in Cerrado. Thus, the selection of more productive genotypes during the dry season is critical to sustain Brazilian livestock production on pastures. Gains with selection should be high for productivity during the dry season in this population, since FGW and TDM showed high magnitudes of heritability estimates, 0.74 and 0.65 , respectively. These estimates were of greater magnitude than those observed for B. humidicola and Panicum maximum (Figueiredo et al. 2012, Braz et al. 2013), also evaluated for TDM in the dry season.

Another important result was that regardless of the season, TRD and SR had higher estimates of $h_{m}^{2}$ than for REG. However, REG should be considered as a main criterion for selection, since it is a combination of the other two variables and best expresses the recovery potential of a genotype after clipping. Gains with selection for regrowth in the dry season are not expected since the genetic variability amongst hybrids was low as explained by the reduced heritability expressed (0.02). REG is an important agronomic trait for it is closely related to pasture management, as it determines forage availability for grazing, carrying capacity and maintenance of animals on the pasture (Silva and Nascimento Junior 2007).

The evaluation of joint data through several clippings increases the number of observations in each plot, reducing the environmental effect, which enables greater precision of evaluation (Resende and Duarte 2007). The accuracy of selection is given by Acgem, which were of medium to high magnitude for every trait in the joint analysis for this experiment, indicating a suitable experimental precision. Similar values of accuracy for agronomic and nutritional characters were observed in progenies of B. humidicola in nine clippings (Figueiredo et al. 2012). In general, estimates of Acgem for the dry season were higher than those for the rainy season for the nutritional traits, but inferior for the agronomic ones (Table 1).

Repeatability estimates based on the mean of the clippings $\left(r_{m}\right)$ ranged from 0.24 for IVD to 0.67 for FGW in the joint analysis, which is considered of low to average magnitude. FGW and TDM had higher estimates for $r_{i}$, regardless of the evaluation period, indicating that for these traits the number of clippings adopted was sufficient to select the best performing hybrids. The opposite happened for REG with estimates of 0.37 for the dry and 0.42 for the rainy season (Table 1). Estimates of low magnitude of $r_{i}$ for REG were also observed for Panicum maximum in a joint analysis considering seven clippings (Braz et al. 2013).

The rgmed parameter provides an indication of the magnitude of variation in the performance of the hybrids among different clippings for each trait (Resende 2002). For estimates of rgmed in the joint analysis considering seven clippings, there was a greater stability in the performance of hybrids for FGW, TDM, NDF and LIG (estimates above 0.80 ), when compared with the other variables. REG had the lowest genetic correlation estimate between clippings (0.34), indicating greater oscillation between the best genotypes in different clippings, which hinders the selection of more stable genotypes for this trait. The high magnitude of rgmed observed during the rainy season for some variables such as NDF and LIG, with 0.85 and 0.90 , respectively, shows that, despite the lower magnitudes of $r_{i}(0.36$ and 0.44 , respectively), high genotypic correlation exists between the clippings, which is important since it allows for the selection of the same superior individuals throughout the clippings (Table 1).

With respect to the average genotypic values for each variable $(\bar{X})$, there was a small reduction of $276 \mathrm{~g} \mathrm{plant}^{-1}$ and $247 \mathrm{~kg} \mathrm{~h}^{-1}$ a for FGW and TDM, respectively, from the rainy to the dry season. Regardless of the season, NDF was always greater than $60 \%$ of the total dry matter (Table 1), which may interfere negatively in the pasture consumption (Van Soest 1994). However, only trials with animal consumption assessments can confirm this fact, since other factors are involved in the final consumption by the animal. The value for digestibility of organic matter during the dry season (74\%) was higher than that for the rainy season (68\%), which together with PB are very important indicators of the nutritive value of the forage (Euclides et al. 2009).

There was large range of variation in genotypic values for each trait in the joint analysis, which can be explained by the larger number of evaluations (seven clippings) considering both the rainy and the dry season. Moreover, it is noticed that the range of variation, expressed in percentage in relation to the BLUP mean, was larger for the agronomic traits when compared with the nutritional traits, regardless of the season (rainy or dry), with some exceptions, such as REG in the dry season, and LIG irrespective of season (Table 1). Although the range for the nutritional value traits was 
smaller, there was genetic variability $(p<0.05$ or $p<0.01)$ for these traits, both in the rainy and in the dry season, with exception of IVD in the rainy season, and REG in the dry season. Thus, the selection for these traits is justifiable.

Significant genetic correlations were detected (using the $t$ test) between agronomic and nutritive value traits, except between NDF and REG in the rainy season (Table 2). Genetic correlations are very helpful in the choice of traits to be evaluated and in establishing indirect selection without losing precision, and thus saving resources and effort (Vencovsky and Barriga 1992, Ramalho et al. 2008). A high and positive genetic correlation (0.98) was observed between FGW and TDM, regardless of the season of evaluation. This indicates that when selecting for the increase in green field weight, total dry matter yield will also be increased.

The possibility to estimate TDM by means of the FGW saves time and reduces the work in the program, since no sampling, weighing, drying and re-weighing is needed to estimate production. In experiments, where a large number of individual plants or hybrids are being evaluated, which is the case in early stages of breeding programs, FGW can be easily used in the selection instead of TDM. Moreover, the fact that for this population of $B$. decumbens the estimate of heritability for FGW was higher than for TDM (Table 1) could mean that a better correlated response could be expected in TDM.

Table 1. Estimates of genotypic variance $\left(\sigma_{g}^{2}\right)$, genotype $x$ clipping interaction variance $\left(\sigma_{g c}^{2}\right)$, individual narrow sense heritability $\left(h_{a t c}^{2}\right)$, heritability based on progeny means $\left(h_{m}^{2}\right)$, accuracy $\left(\right.$ Acgem), repeatability coefficient of clipping means $\left(r_{m}\right)$, genotypic correlation among clippings (rgmed), general mean $(\bar{X})$ and range of $B$. decumbens progenies

\begin{tabular}{|c|c|c|c|c|c|c|c|c|c|}
\hline \multicolumn{10}{|c|}{ Joint (seven clippings) } \\
\hline Parameter & $\mathbf{F G W}^{1}$ & TDM & TRD & SR & REG & $\mathrm{CP}$ & IVD & NDF & LIG \\
\hline$\sigma_{g}^{2}$ & $243484.330 * *$ & $371814.520 * *$ & $0.061 * *$ & $0.065^{* *}$ & $0.058 * *$ & $0.637^{* *}$ & $2.656^{* *}$ & $2.337^{* *}$ & $0.079 * *$ \\
\hline$\sigma_{g c}^{2}$ & $29220.220^{* *}$ & $46356.410^{* *}$ & $0.032 * *$ & $0.016^{* *}$ & $0.055^{* *}$ & $0.165^{* *}$ & $1.372 * *$ & $0.258^{* *}$ & $0.008^{* *}$ \\
\hline$h_{a t c}^{2}$ & 0.615 & 0.523 & 0.202 & 0.273 & 0.143 & 0.306 & 0.139 & 0.335 & 0.376 \\
\hline$h_{m}^{2}$ & 0.799 & 0.776 & 0.688 & 0.743 & 0.566 & 0.585 & 0.512 & 0.740 & 0.756 \\
\hline Acgem & 0.894 & 0.881 & 0.829 & 0.862 & 0.752 & 0.765 & 0.716 & 0.860 & 0.870 \\
\hline$r_{m}$ & 0.672 & 0.617 & 0.398 & 0.420 & 0.400 & 0.457 & 0.241 & 0.403 & 0.484 \\
\hline rgmed & 0.806 & 0.800 & 0.487 & 0.670 & 0.347 & 0.659 & 0.492 & 0.819 & 0.835 \\
\hline $\bar{x}$ & 1484.881 & 1926.708 & 1.980 & 2.410 & 3.390 & 14.056 & 70.598 & 67.606 & 2.514 \\
\hline Range\# & 150.595 & 289.879 & 53.140 & 43.039 & 32.264 & 22.467 & 10.096 & 11.368 & 50.128 \\
\hline \multicolumn{10}{|c|}{ Rainy season (five clippings) } \\
\hline Parameter & FGW & TDM & TRD & SR & REG & $\mathbf{C P}$ & IVD & NDF & LIG \\
\hline$\sigma_{g}^{2}$ & $253338.790 * *$ & $374380.220 * *$ & $0.046^{* *}$ & $0.065 * *$ & $0.065 * *$ & $0.306^{*}$ & 1.197 & $1.887^{* *}$ & $0.061 * *$ \\
\hline$\sigma_{g c}^{2}$ & $32714.110^{* *}$ & $40963.760 * *$ & $0.031^{* *}$ & $0.013 * *$ & $0.037 * *$ & $0.272 * *$ & $1.647^{* *}$ & $0.159 * *$ & $0.003^{* *}$ \\
\hline$h_{a t c}^{2}$ & 0.574 & 0.497 & 0.171 & 0.295 & 0.170 & 0.162 & 0.083 & 0.289 & 0.345 \\
\hline$h_{m}^{2}$ & 0.769 & 0.749 & 0.585 & 0.724 & 0.571 & 0.311 & 0.249 & 0.669 & 0.729 \\
\hline Acgem & 0.877 & 0.866 & 0.765 & 0.851 & 0.755 & 0.557 & 0.499 & 0.818 & 0.854 \\
\hline$r_{m}$ & 0.642 & 0.602 & 0.353 & 0.446 & 0.419 & 0.349 & 0.222 & 0.369 & 0.443 \\
\hline rgmed & 0.795 & 0.820 & 0.430 & 0.709 & 0.465 & 0.359 & 0.267 & 0.856 & 0.903 \\
\hline $\bar{x}$ & 1567.077 & 2001.705 & 1.899 & 2.339 & 3.237 & 14.013 & 68.674 & 67.974 & 2.695 \\
\hline Range\# & 147.733 & 319.006 & 42.060 & 44.239 & 36.638 & 10.165 & 4.388 & 8.752 & 40.578 \\
\hline \multicolumn{10}{|c|}{ Dry season (two clippings) } \\
\hline Parameter & FGW & TDM & TRD & SR & REG & $\mathrm{CP}^{+}$ & IVD $^{+}$ & $\mathrm{NDF}^{+}$ & LIG $^{+}$ \\
\hline$\sigma_{g}^{2}$ & $196161.780 * *$ & $319839.760 * *$ & $0.078^{* *}$ & $0.045^{* *}$ & 0.005 & $0.548^{* *}$ & $2.995^{* *}$ & $1.868 * *$ & $0.068^{* *}$ \\
\hline$\sigma_{g c}^{2}$ & $24121.460 * *$ & $71270.040^{* *}$ & $0.042^{* *}$ & $0.031 * *$ & $0.111^{* *}$ & - & - & - & - \\
\hline$h_{\text {atc }}^{2}$ & 0.786 & 0.636 & 0.211 & 0.186 & 0.012 & 0.370 & 0.188 & 0.432 & 0.409 \\
\hline$h_{m}^{2}$ & 0.740 & 0.647 & 0.480 & 0.407 & 0.024 & 0.709 & 0.568 & 0.729 & 0.711 \\
\hline Acgem & 0.860 & 0.804 & 0.693 & 0.638 & 0.154 & 0.842 & 0.753 & 0.854 & 0.843 \\
\hline$r_{m}$ & 0.809 & 0.711 & 0.433 & 0.408 & 0.372 & - & - & - & - \\
\hline rgmed & 0.803 & 0.692 & 0.480 & 0.421 & 0.022 & - & - & - & - \\
\hline $\bar{x}$ & 1291.060 & 1754.990 & 2.180 & 2.590 & 3.770 & 14.330 & 74.690 & 66.660 & 2.150 \\
\hline Range\# & 128.040 & 125.990 & 38.330 & 24.070 & 1.440 & 15.250 & 8.170 & 7.950 & 33.630 \\
\hline
\end{tabular}

${ }^{1}$ Field green weight (FGW), g plant ${ }^{-1}$; total dry matter (TDM), $\mathrm{kg} \mathrm{ha}^{-1}$; speed of regrowth (SR), visual score; tiller regrowth density (TRD), visual score; final regrowth ability (REG), score; crude protein (CP), \% of dry matter; in vitro organic matter digestibility (IVD), \%; neutral detergent fiber (NDF), \% of dry matter; lignin (LIG), \% of dry matter. * $p<0.05$ and ${ }^{* *} p<0.01$ by the $\chi^{2}$ test. ${ }^{+}$Evaluated in only one clipping in the dry season. " Ratio of the difference between the maximum and minimum predicted genotypic value (BLUP) in relation to the general mean, expressed as percentage: [(BLUP max - BLUP min)/(BLUP average)] $\times 100$. 


\section{FI Matias et al.}

In general, the estimates of genetic correlations followed a similar standard of magnitude and significance between the joint analyses, the rainy and the dry seasons analyses (Table 2). Thus, the correlations between the agronomic traits, the correlations between nutritive value traits and the correlations between the two groups were proportional in all the situations. The effect of the correlation may be due to the action of one gene over one or more traits simultaneously, or to genetic linkage (Ramalho et al. 2008). This could be happening between the nutritional variables CP and IVD, CP and NDF, LIG and NDF, LIG and IVD and NDF with IVD. Similar results in terms of correlations were observed in full sib progenies of $B$. humidicola (Figueiredo et al. 2012).

Several papers in the literature have already described the positive correlation among agronomic traits, such as FGW and TDM, among nutritive value traits, such as NDF and LIG, the positive correlation between CP and IVD, and the negative correlation between NDF and LIG (Figueiredo et al. 2012, Braz et al. 2013). This happens because these nutritional components are directly related to the morphological structure of the plant. Under high temperatures, with moisture and light, the plant accumulates lignin in the cell wall and accelerates its metabolism, reduces the concentrations of proteins, lipids and soluble carbohydrates, and consequently reduces IVD (Van Soest 1994).

Table 2. Genetic correlation estimates between agronomic and nutritive value traits in progenies of Brachiaria decumbens, considering several clippings

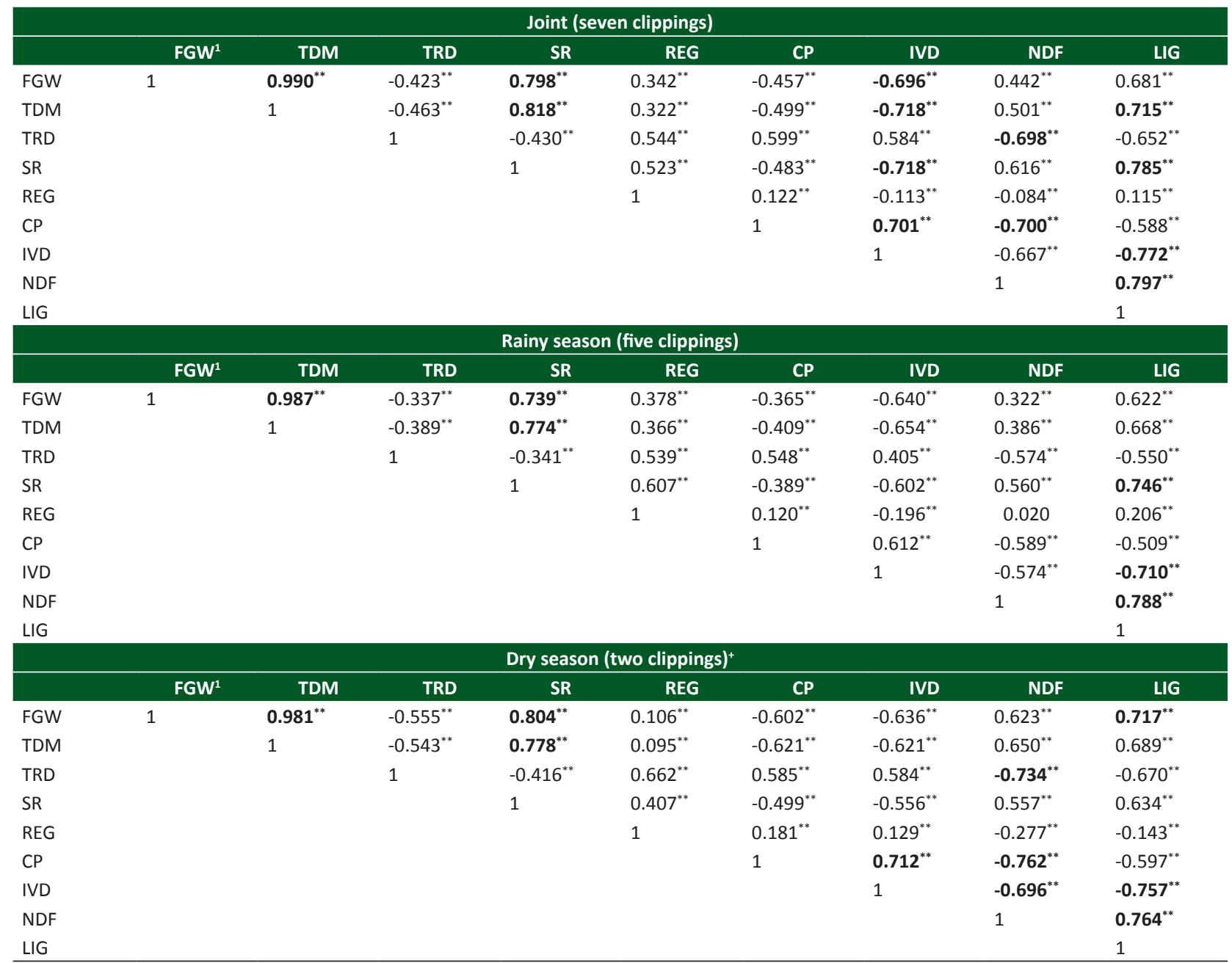

${ }^{1}$ Field green weight (FGW), g plant ${ }^{-1}$; total dry matter (TDM), $\mathrm{kg} \mathrm{ha}^{-1}$; speed of regrowth (SR), score; tiller regrowth density (TRD), score; final regrowth ability (REG), score; crude protein (CP), \% of dry matter; in vitro organic matter digestibility (IVD), \%; neutral detergent fiber (NDF), \% of dry matter; lignin (LIG), \% of dry matter. ${ }^{*} p<0.05$ e ${ }^{* *}$ $p<0.01$ by the $t$ test. ${ }^{+}$Evaluation in the dry season using two clippings for FGW, TDM, TRD, SR and REG and only one for CP, IVD, NDF e LIG. 
Another association observed was a negative correlation among the agronomic traits FGW, TDM and SR with the nutritive value trait CP and IVD, being more pronounced with the last one, which varied from -0.69 to -0.72 (Table 2). As the plants grow and the cell wall thickens, there is a larger synthesis of LIG and NDF, since they have structural function. As a consequence, there is reduction in the accumulation of $\mathrm{CP}$, which may become deficient to the rumen microorganisms, and thus reduces IVD. IVD is also related to the structure of the plant since mesophyll and parenchyma cells are rapidly digested, whereas epidermis, bundle sheath cells and xylem are very slowly or not even digested due to the presence of LIG (Van Soest 1994, Pereira et al. 2011). In this experiment, there was better digestibility during the dry season (Table 1), which may help the nutrition of grazing animals, with more protein and digestibility.

Other estimates of correlations, regardless of the evaluation phase, joint analysis, rainy, or dry season single analysis, despite being significant, were not considered high enough to guarantee indirect selection. Some examples are the genetic correlation between REG and FGW, REG and TDM and also among nutritional variables (Table 2). On the other hand, the estimates of positive correlation between REG and TRD and also REG and SR indicate that if REG is improved, there will be indirect gains in TRD and SR.

When important traits are negatively correlated, one should try to select an ideotype to avoid the loss of an important trait when selecting for a specific one (Borém and Miranda 2013), as observed in the present study between FGW and TDM in relation to CP and IVD. To obtain this ideotype, one can select considering several traits simultaneously using selection indexes, such as the additive or multiplicative indexes. The weights assigned in the selection indexes should be defined as a function of the traits to be improved in the population (Cruz et al. 2012). Thus, to estimate genetic parameters in a tropical forage breeding program, it is essential to indicate the possibility of gains with selection and/ or correlated response for the traits of interest (Valle et al. 2009, Cruz et al. 2012). Furthermore, estimates of genetic correlation among variables allow for more efficient selection strategies and for the use of selection indexes adequate to the objectives of the program.

In conclusion, the population of Brachiaria decumbens evaluated in this study has significant genetic variability and sufficient magnitude to successfully practice selection. The genetic variability present along with estimates of heritability of medium to high magnitude concurs for gains with selection for all the traits considered. Furthermore, the significant genetic correlations observed among agronomic and nutritional traits, as well as between the two groups of traits allow for indirect selection and/or for the use of selection indexes, considering these associations in order to rank and identify the best genotypes.

\section{ACKNOWLEDGEMENTS}

The authors are grateful for the financial support given by the Association for the Promotion of Research in Tropical Forages - UNIPASTO, and by the Foundation for the Development of Education, Science and Technology of the State of Mato Grosso do Sul - FUNDECT. The authors thank Embrapa Beef Cattle for the opportunity to develop this research, and the Coordination for the Improvement of Higher Education Personnel - CAPES, for the scholarship.

\section{REFERENCES}

Alves GF, Figueiredo UJ, Pandolfi Filho AD, Barrios SC and Valle CB (2013) Breeding strategies for Brachiaria spp. to improve productivity - an ongoing project. Tropical Grasslands-Forrajes Tropicales 2: 1-3.

Barrios SC, Valle CB, Alves GF, Simeão RM and Jank L (2013) Reciprocal recurrent selection in the breeding of Brachiaria decumbens. Tropical Grasslands-Forrajes Tropicales 1: 52-54.

Borém A and Miranda GV (2013) Melhoramento de plantas. Editora UFV, Viçosa, 523p.

Braz TGS, Fondry DM, Jank L, Resende MDV, Martuscello JA and Simeão RM (2013) Genetic parameters of agronomic characters in Panicum maximum hybrids. Revista Brasileira de Zootecnia 42: 231-237.
Cruz CD, Regazzi AJ and Carneiro PCS (2012) Modelos biométricos aplicados ao melhoramento genético. Editora UFV, Viçosa, 514p.

Euclides VPB, Macedo MCM, Valle CB, Difante GS, Barbosa RA and Cacere ER (2009) Valor nutritivo da forragem e produção animal em pastagens de Brachiaria brizantha. Pesquisa Agropecuária Brasileira 44: 98-106.

Figueiredo UJ, Nunes JAR and Valle CB (2012) Estimation of genetic parameters and selection of Brachiaria humidicola progenies using a selection index. Crop Breeding and Applied Biotechnology 12: 237-244.

Jank L, Barrios SC, Valle CB, Simeão RM and Alves GF (2014) The value of improved pastures to Brazilian beef production. Crop and Pasture Science 65: 1132-1137. 


\section{FI Matias et al.}

Jank L, Valle, CB, Resende RMS (2011) Breeding tropical forages. Crop Breeding and Applied Biotechnology S1: 27-34.

Marten GC, Shenk JS and Barton FE (1985) Near infrared reflectance spectroscopy (NIRS), analysis quality. USDA, Washington, 110p.

Mateus RG, Barrios SC, Figueiredo UJ and Valle CB (2013) Agronomic evaluation of 324 intraspecific hybrids of Brachiaria decumbens in Brazil. Tropical Grasslands-Forrajes Tropicales 1: 99-100.

Mendonça SA, Barrios SC, Figueiredo UJ, Alves GF and Valle CB (2013) Agronomic and nutritional evaluation of intraspecific crosses in Brachiaria decumbens. Tropical Grasslands-Forrajes Tropicales 1: 103-105.

Miles JW (2007) Apomixis for cultivar development in tropical forage grasses. Crop Science 47 (S3): S238-S249.

Pereira EA, Dall'Agnol M, Nabinger C, Huber KGC, Montardo DP and Genro TCM (2011) Produção agronômica de uma coleção de acessos de Paspalum nicorae Parodi. Revista Brasileira de Zootecnia 40: 498-508.

Ramalho MAP (2005) Experimentação em genética e melhoramento de plants. Editora UFLA, Lavras, 326p.

Ramalho MAP, Santos JB and Pinto CB (2008) Genética na agropecuária. Editora UFLA, Lavras, 463p.

Resende MDV (2007) SELEGEN-REML/BLUP: sistema estatístico e seleção genética computadorizada via modelos lineares mistos. Embrapa Florestas, Colombo, 17p.

Resende MDV and Duarte JB (2007) Precisão e controle de qualidade em experimentos de avaliação de cultivares. Pesquisa Agropecuária Tropical (Agricultural Research in the Tropics) 37: 182-194.

Resende MDV (2002) Genética biométrica e estatística no melhoramento de plantas perenes. Embrapa Informação Tecnológica, Brasília, 975p.

Silva SC and Nascimento Junior D (2007) Avanços na pesquisa com plantas forrageiras tropicais em pastagens: características morfofisiológicas e manejo do pastejo. Revista Brasileira de Zootecnia 36: 121-138.

Simioni C and Valle CB (2009) Chromosome duplication in Brachiaria (A. Rich.) Stapf allows intraspecific crosses. Crop Breeding and Applied Biotechnology 9: 328-333.

Souza Sobrinho F, Lédo FJS and Kopp MM (2011) Estacionalidade e estabilidade de produção de forragem de progênies de Brachiaria ruziziensis; Seasonality and stability of forage production of Brachiaraia ruziziensis progenies. Ciência Agrotecnologia 35: 685691.

Steel RGD, Torrie JH and Dickey DA (1997) Principles and procedures of statistics: A biometrical approach. $3^{\text {rd }}$ edn, McGraw-Hill, New York, 666p.

Valle CB, Jank L and Resende RMS (2009) O melhoramento de forrageiras tropicais no Brasil. Revista Ceres 56: 460-472.

Van Soest PJ (1994) Nutritional ecology of the ruminant. Cornell University Press, Ithaca, 476p.

Vencovsky $R$ and Barriga P (1992) Genética biométrica no fitomelhoramento. Revista Brasileira de Genética, Ribeirão Preto, 496p. 